\title{
ANALISIS PENGARUH KUALITAS SUMBER DAYA MANUSIA, KOMUNIKASI, DAN MOTIVASI KERJA TERHADAP KINERJA KARYAWAN PADA PT. ALEXA MEDIKA MEDAN
}

\author{
Sahat Simbolon \\ Dosen Pascasarjana Institut Bisnis IT\& B Medan \\ email : sahats_simbolon@yahoo.com
}

\begin{abstract}
The purpose of this study is to describe the influence of the quality of human resources, communication, and work motivation on employee performance at PT Alexa Medika Medan. This research was conducted at PT. Alexa Medika Medan which lasts for 5 (five) months, starting from May 2019 to September 2019.This research uses nonprobability sampling method. The population in this study were employees at PT. AlexaMedika Medan as many as 83 people. Determination of the number of samples using Sugiyono's opinion, so that the total sample is all employees of PT AlexaMedika Medan, amounting to 83 people. Data collection methods in this study used a questionnaire to collect data from human resources, communication, work motivation, and employee performance variables. The analysis technique used is validity test, reliability test, descriptive analysis, classic assumption test, double regression linear analysis, double correlation coefficient linear test, partial hypothesis test or T test, simultaneous hypothesis test or F test, and coefficient determination. Descriptive analysis result for the quality of human resources and communication are good. The result of descriptive analysis for employee performance fall into the quite good category and work motivation is in not very good category. Based on partial analysis, the variable quality of human resources has a positive and significant effect on the performance of employees of PT AlexaMedika Medan, communication has a positive and significant effect on the performance of employees of PT AlexaMedika Medan, and work motivation has a positive and significant effect on the performance of employees of PT AlexaMedika Medan. Simultaneously, there is a positive and significant influence on the quality of human resources, communication, and work motivation on the performance of employees of PT AlexaMedika Medan. From the coefficient of determination that employee performance is influenced by the quality of human resources, communication, and work motivation by $58.5 \%$. While the remaining $41.5 \%$ of employee performance is influenced by other variables not observed in this study.
\end{abstract}

Keywords: Human Resource Quality, Communication, Work Motivation, Employee's Performance

\section{PENDAHULUAN}

PT Alexa Medika Medan merupakan perusahaan yang bergerak di bidang kesehatan. Perusahaan yang sedang berkembang ini sedang melakukan ekspansi dengan berbisnis secara nasional dan mengimplementasikan beberapa program baru di komputer. Sistem atau software di PT Alexa Medika Medan diperbaharui setiap tahunnya untuk pelancaran kegiatan perusahaan seperti meningkatkan pemasaran melalui e-commerce, laporan yang dibuat melalui sistem dapat lebih akurat, memperlancar arus pendistribusian produk, dan lain lain. Dengan adanya peningkatan sistem, diharapkan agar kinerja karyawan dapat meningkat dan target penjualan dapat tercapai setiap tahunnya.

Pimpinan mengevaluasi kembali kinerja karyawan dengan menggunakan salah satu subindikator pengukur kinerja karyawan, yaitu dengan membandingkan jumlah jam lembur dan kesalahan dalam pekerjaan. Dari tabel 1.2 di bawah berikut, dapat diketahui adanya penurunan kinerja karyawan yang dilihat dari peningkatan jumlah jam lembur dan jumlah kesalahan yang dilakukan karyawan pada tahun 2016-2018.Pada kesalahan yang umum 
terjadi adalah kesalahan interpretasi data, kesalahan input data, yang menjadi sebab salah perhitungan data dan analisis data.

Penurunan kinerja karyawan dapat disebabkan oleh rendahnya kualitas sumber daya manusia terutama dari segi kualitas intelektual. Serta dikarenakan komunikasi yang tidak berjalan dengan baik dari segi kurangnya pemberian informasi berupa pelatihan dan kurangnya pemberian motivasi yang dibutuhkan.Sumber daya manusia terbentuk dari kemampuan sekelompok individu yang membentuk tenaga kerja dari suatu organisasi. Sumber daya manusia merupakan aspek yang memegang peran penting di dalam suatu organisasi karena sumber daya manusia merupakan penggerak utama dan kunci serius di dalam lingkungan kerja.

Melihat besarnya kontribusi sumber daya manusia bagi keberhasilan perusahaan maka perusahaan perlu membina dan mempertahankan suatu kualitas sumber daya manusia. Hal ini memiliki arti bahwa selain mengadakan perekrutan, penerimaan dan penempatan tenaga kerja, perusahaan juga harus mampu memelihara dan mempertahankan karyawannya melalui peningkatan kualitas sumber daya manusia.

Kualitas sumber daya manusia ini harus terus menerus ditingkatkan guna memperbaiki dan meningkatkan kinerja, serta melatih diri karyawan sehingga karyawan mampu menyesuaikan diri dalam menghadapi perkembangan zaman yang terjadi. Dalam hal ini, peranan perusahaan sangat berpengaruh dan diperlukan untuk mengembangkan kualitas sumber daya manusia. Sumber daya manusia yang berkualitas dicerminkan dari kemampuannya untuk bekerja secara efektif dan efisien, kecakapan dalam bekerja dan cara bekerja yang profesional.

Tujuan utama manajemen sumber daya manusia adalah untuk meningkatkan kontribusi pegawai terhadap organisasi dalam rangka mencapai produktivitas organisasi yang bersangkutan. Hat ini dapat dipahami karena semua kegiatan organisasi dalam mencapai tujuan, tergantung kepada manusia yang mengelolah organisasi yang bersangkutan. Oleh sebab itu, sumber daya manusia tersebut harus dikelola agar dapat berdaya guna dan berhasil guna dalam mencapai tujuan organisasi.

Dari segi kualitas sumber daya manusia, karyawan di PT Alexa Medika Medan tidak semuanya menguasai Bahasa Inggris sehingga mempunyai kendala dalam menjalankan program yang secara keseluruhan menggunakan Bahasa Inggris. Kurangnya manajemen sumber daya manusia dari PT Alexa Medika Medan seperti kurangnya pelatihan mengenai program baru memperkeruh keadaan dan membuat karyawan kesulitan bekerja. Selain dari kualitas sumber daya manusia, faktor lain yang memengaruhi kinerja karyawan adalah komunikasi. Pentingnya dari perencanaan yang efektif tidak dapat dijalankan jika ada penghalang berupa komunikasi yang tidak efektif. Pemikiran awal, tujuan pesan, media, dan waktu harus direncanakan secara efektif. Gagasan perencanaan perusahaan adalah untuk memberikan tujuan yang sama ke seluruh pegawai di suatu organisasi. Semua orang di organisasi harus mengerti tujuan organisasi. Perencanaan yang paling penting harus dikomunikasikan ke seluruh tingkatan organisasi.

Komunikasi merupakan proses pengiriman pesan antar individu dan atau organisasi yang dapat memberikan hasil berupa pengertian. Untuk menciptakan iklim kerja yang kondusif diperlukan komunikasi yang baik dan lancar. Komunikasi efektif juga mutlak diperlukan dalam suatu organisasi. Komunikasi yang efektif mendukung terciptanya lingkungan kerja yang nyaman dan menyenangkan, serta terciptanya semangat kerja yang tinggi. Komunikasi yang efektif artinya pimpinan dapat memberikan perintah kerja atau tugas kepada bawahannya secara lisan dan tertulis dengan baik dan jelas sehingga para karyawan dapat mengerjakan tugasnya sesuai degan perintah atasannya sehingga kesalahan dalam mengerjakan tugas dapat ditekan sekecil mungkin. 
Penyediaan media komunikasi yang lengkap juga mempermudah karyawan dalam pengerjaan tugas-tugasnya sehingga dapat memberikan kontribusi yang optimal bagi perusahaan atau lembaga di mana mereka bekerja. Karyawan memiliki kebutuhan dan keinginan informasi untuk mengetahui tugas-tugasnya dan mengerti seluruh tujuan dan strategi perusahaan. Keterbukaan dan kejujuran kebijakan komunikasi harus dibangun oleh pimpinan dan harus diterima oleh setiap bawahan. Komunikasi dari manajemen ke karyawan, karyawan ke pihak manajemen harus jujur dan dibangun berdasarkan kepercayaan.

Faktor lain yang memengaruhi kinerja karyawan adalah motivasi kerja. Motivasi memainkan peran yang penting dalam mentransformasi organisasi. Oleh karena itu, pemimpin harus mengidentifikasi kebutuhan dan halangan yang dihadapi pegawai dan mengerti faktor-faktor yang dapat meningkatkan produktivitas. Pegawai yang termotivasi akan lebih mempunyai kinerja yang memuaskan, dan sangat berkomitmen terhadap pekerjaan dan organisasi tempat dia bekerja pada jangka waktu yang lama.

Setiap pegawai harus diawasi dan dievaluasi kinerjanya. Kinerja pegawai dapat ditingkatkan melalui contoh yang baik dari pemimpin dan motivasi yang cukup ke pegawai. Motivasi kerja adalah salah satu cara terbaik untuk mencapai tujuan organisasi dengan input yang optimal.Pegawai memandang perubahan yang seharusnya baik tersebut menjadi beban karena pegawai harus mempelajari hal yang baru lagi. Kurangnya motivasi kerja menjadi salah satu aspek pemikiran pembebanan karyawan tersebut. Perusahaan harus menciptakan lingkungan kerja yang dapat memotivasi karyawan agar pekerjaan dapat dilakukan secara efektif dan efisien.

Dalam menjalankan kegiatan operasional, perusahaan membutuhkan karyawan yang dapat bekerja sesuai dengan harapan perusahaan dalam mencapai tujuan yang ditetapkan oleh perusahaan. Oleh karena itu, perusahaan harus dapat mengelola manajemen sumber daya manusia, menciptakan komunikasi yang efektif, dan motivasi kerja yang kurang.

Berdasarkanidentifikasimasalah, dirumuskanmasalahpenelitianadalah:

1. Bagaimana pelaksanaan kualitas sumberdaya manusia, komunikasi, motivasi kerja dan kinerja karyawan di PT Alexa Medika Medan?

2. Apakah kualitas, komunikasi, motivasi kerja berpengaruh dan signifikan terhadap kinerja karyawanpada PT Alexa Medika Medan?

3. Apakah kualitas sumber daya manusia, komunikasi, dan motivasi kerja berpengaruh dan signifikan terhadap kinerja karyawan pada PT Alexa Medika Medan?

\section{Pengertian KualitasSumberDayaManusia}

\section{TINJAUAN PUSTAKA}

Menurut Notoatmodjo (2019:18), kualitas sumber daya manusia adalah menyangkut dua aspek yaitu aspek fisik (kualitas fisik) dan aspek non fisik (kualitas non fisik) yang menyangkut kemampuan bekarja, berpikir, dan keterampilah. Menurut Rahardjo (2015:76), kualitas sumber daya manusia itu tidak hanya ditentukan oleh Pendidikan atau kadar pengetahuannya. pengalaman, atau kematangannya dan sikapnya serta nilai-nilai yang dimilikinya; aspek biologi juga memiliki peran dan arti penting bagi peningkatan kualitas sumber daya manusia.

Robbins (2015:19) mengatakan bahwa kualitas sumber daya manusia dapat ditingkatkan melalui pelatihan dan pemberian motivasi kerja yang adil termasuk berbagai fasilitas kesejahteraan karyawan. Kualitas sumber daya manusia dapat diukur dari keberhasilan peningkatan kemampuan teoritis, peningkatan kemampuan teknis, peningkatan kemampuan konseptual, peningkatan moral dan peningkatan keterampilan teknis. Dari 
pengertian di atas disimpulkan bahwa kualitas sumber daya manusia adalah sumberdaya yang memiliki kompetensi baik dari aspek fisik maupun aspek intelektual.

Menurut Danim (2015:76), indikator dari kualitas sumber daya manusia adalah (1) kualitas fisik dan kesehatan meliputi: memiliki kesehatan yang baik serta kesegaran jasmani, memiliki postur tubuh yang baik yang disebabkan oleh peningkatan gizi yang baik, memiliki tingkat kehidupan yang layak dan manusiawi, (2) kualitas intelektual (pengetahuan dan keterampilan) meliputi memiliki kemampuan pendidikan pada jenjang yang lebih tinggi, memiliki tingkat ragam dan kualitas pendidikan serta keterampilan yang relevan dengan memperhatikan dinamika lapangan kerja baik yang di tingkat lokal, nasional maupun internasional, memiliki penguasaan bahasa, meliputi bahasa nasional, bahasa ibu, (daerah) dan sekurang-kurangnya satu bahasa asing, memiliki pengetahuan dan keterampilan di bidang ilmu pengetahuan dan teknologi yang sesuai dengan tuntutan industrialisasi, (3) kualitas spiritual (kejuangan) meliputi taat menjalankan agama dan kepercayaan terhadap Tuhan Yang Maha Esa, serta toleransi yang tinggi dalam kehidupan beragama, memiliki semangat yang tinggi dan kejuangan yang tangguh baik sebagai individu maupun sebagai masyarakat, jujur, yang dilandasi kesamaan antara pikiran, perkataan dan perbuatan serta tanggung jawab yang dipikulnya.

\section{Pengertian Komunikasi}

Menurut Handoko (2016:272), komunikasi adalah proses penyampaian pesan dari satu invidu ke individu lainnya. Komunikasi adalah elemen yang sangat penting dalam mencapai tujuan organisasi karena komunikasi dapat menyalurkan ide dan informasi dari satu individu ke individu lainnya atau ke banyak orang. Komunikasi adalah bentuk interaksi manusia yang saling memengaruhi satu sama lain, sengaja atau tidak, secara verbal maupun non verbal (Wiryanto,2015).

Menurut Notoatmodjo (2019:179), dalam mengelola sumber daya yang berorientasi pada kinerja, diperlukan proses komunikasi yang terbuka dan berkelanjutan dengan menciptakan visi bersama dan pendekatan strategis secara terpadu sebagai kekuatan pendorong untuk mencapai tujuan organisasi.Menurut Wiryanto (2015:167), indikator komunikasi adalah (1) tujuan komunikasi, (2) media komunikasi, (3) pengelolaan komunikasi, (4) delegasi wewenang, (5) pemberian informasi.

\section{Pengertian MotivasiKerja}

Motivasi kerja adalah kegiatan memfasilitasi karyawan dengan insentif untuk mendorong karyawan bekerja sesuai dengan cara yang diinginkan oleh organisasi (Takacs, 2018:1). Kinerja karyawan sangat dipengaruhi oleh motivasi kerja. Karyawan yang stress, lelah dan mempunyai beban hati dan pikiran umumnya mempunyai kinerja kerja yang kurang bagus; sementara, karyawan dengan motivasi kerja yang tinggi akan lebih fokus untuk bekerja mencapai tujuan organisasi sehingga lebih produktif dan mempunyai kinerja yang bagus. Motivasi kerja adalah kondisi mental yang mendorong dilakukannya suatu tindakan dan memberikan kekuatan yang mengarah kepada pencapaian kebutuhan, memberi kepuasan ataupun mengurangi ketidakseimbangan (Martoyo, 2016).

Manajemen yang lebih tinggi harus mengambil petunjuk bahwa kinerja mungkin bukan dipengaruhi faktor-faktor motivasi eksternal tetapi bisa menjadi efek ketidakpuasan dari tugas dan output yang dicapai. Mereka harus fokus pada pengembangan pekerjaan yang melibatkan karyawan dan memotivasi serta memenuhi harapan. Juga harus disadari bahwa kinerja karyawan juga dipengaruhi secara negatif oleh stres di tempat kerja, oleh karena itu penting untuk mengevaluasi proses dan praktik saat ini yang bertanggung jawab untuk menciptakan situasi yang penuh tekanan agar tidak memengaruhi kinerja. Merancang konten 
pekerjaan yang lebih menarik dan pengembangan pekerjaan bisa menjadi salah satu strategi untuk memotivasi karyawan (Lunenburg, 2018:29).

Menurut Ochola (2018:2), berikut beberapa cara yang dapat meningkatkan motivasi kerjamelalui training dan workshops, gayakepemimpinan yang bagus, mengingatkan lingkungan kerja, employee remuneration, fasilitas organisasi, mentoring, coaching, konseling, dan asimilasi

\section{Pengertian Kinerja Karyawan}

Mangkunegara (2019:67) menyatakan kinerja pegawai (prestasi kerja) adalah hasil kerja secara kualitas dan kuantitas yang dicapai oleh seseorang pegawai dalam melaksanakan tugasnya sesuai dengan tanggung jawab yang diberikan kepadanya. MenurutPrawirosentono (2019:2), hasilkerja (performance) adalah hasil kerja yang dapat dicapai oleh seseorang atau kelompok orang dalam suatu organisasi sesuai dengan wewenang dan tanggung jawab masing-masing dalam rangka upaya mencapai tujuan organisasi yang bersangkutan secara legal, tidak melanggar hukum dan sesuaidengan moral maupun etika.

Menurut Mangkunegara (2019:18), terdapat beberapa indikator-indikator dalam menilai kinerja karyawan yaitu: (1) kualitas kerja, (2) kuantitas kerja, (3) kreativitas kerja, (4) efektivitas kerja, (5) efisienși kerja, (6) kedisiplinan, (7) kerjasama, dan (8) loyalitas.

\section{METODE PENELITIAN}

Penelitian ini dilakukan pada PT. AlexaMedikaMedan yang beralamat di KompMultatuli Blok E No 36, Medan. Ruang lingkup penelitian ini adalah kualitassumberdayamanusia, komunikasi, motivasikerjadan kinerja karyawan. Populasi dalampenelitian iniadalah seluruh karyawan bagian produksipada PT. AlexaMedikaMedantahun 2019 sebanyak 83 orang. Teknik penentuan sampel adalah metode sensusartinya seluruh anggota populasi menjadi sampel penelitian.

\section{Operasionalisasi Variabel}

Definisi operasional variabel adalah penjelasan mengenai variabel yang akan diteliti. Variabel-variabel yang dianalisis dalam penelitian ini adalah sebagai berikut:

1. Variabelbebas (independent variable) terdiridarikualitassumberdayamanusia, komunikasi, motivasikerja

2. Variabel bebas (dependent variable) terdiri dari kinerjakaryawan.

\section{Metode Pengumpulan Data}

Teknik pengumpulan data yang digunakan adalah kuesioner dan dokumentasi.

\section{Metode Analisis}

\section{AnalisisDesakriptif}

2. UjiAsumsiKlasik

\section{Analisis Regresi Linear Berganda}

Kasmadi dan Sunariah (2014:141) mengungkapkan bahwa persamaan yang digunakandalamanalisisregresi linear bergandaadalahsebagaiberikut: $\mathrm{Y}=\mathrm{a}+b_{1} \cdot X_{1}+b_{2} \cdot X_{2}+b_{3} \cdot X_{3}+\varepsilon ;$ dimana $: \mathrm{Y}=$ Variabel terikat, $\mathrm{a}=$ konstanta, $\mathrm{b}=$ koefisien variabel penelitian, $X=$ variabel bebas dan $\varepsilon=$ epsilon.

\section{Analisis Deskriptif}

\section{HASIL PENELITIAN DAN PEMBAHASAN}


Analisis deskriptif dilakukan untuk mengetahui berapa nilai frekuensi dan persentase yang diperoleh dari masing-masing alternatif jawaban yang diberikan oleh setiap responden dalam kuesioner penelitian. Deskripsi skor penilaian jawaban dari masing-masing variabel di dalam penelitian ini adalah sebagai berikut : yang menjawab sangat setuju adalah dengan rata-rata $28,67 \%$, responden yang menjawab setuju adalah rata-rata $47,23 \%$, responden yang menjawab kurang setuju adalah rata-rata $18,31 \%$, responden yang menjawab tidak setuju rata-rata sebanyak $5,06 \%$, dan responden yang menjawab sangat tidak setuju rata-rata $0,72 \%$. Dari keseluruhan jawaban responden, terdapat $18,31 \%$ responden menjawab kurang setuju dan terdapat $75,9 \%$ responden yang memilih jawaban sangat setuju dan setuju dimana persentase jawaban mereka tersebut berada di antara skor penilaian 70 sampai dengan 79 dengan katergori baik.Sementara itu, terdapat 5,78\% responden menjawab tidak setuju, dan sangat tidak setuju.

Responden yang menjawab sangat setuju adalah dengan rata-rata 40,96\%, responden yang menjawab setuju adalah rata-rata $36,51 \%$, responden yang menjawab kurang setuju adalah rata-rata $14,46 \%$, responden yang menjawab tidak setuju rata-rata sebanyak $6,51 \%$, dan responden yang menjawab sangat tidak setuju rata-rata 1,57\%. Dari keseluruhan jawaban responden, terdapat 14,46\% karyawan menjawab kurang setuju dan terdapat $77,47 \%$ responden yang memilih jawaban sangat setuju dan setuju dimana persentase jawaban mereka tersebut berada di antara skor penilaian 70 sampai dengan 79 dengan katergori baik.Sementara itu, terdapat $8,08 \%$ responden menjawab tidak setuju dan sangat tidak setuju.

Responden yang menjawab sangat setuju adalah dengan rata-rata 2,21\%, responden yang menjawab setuju adalah rata-rata $46,18 \%$, responden yang menjawab kurang setuju adalah rata-rata $48,8 \%$, responden yang menjawab tidak setuju rata-rata sebanyak 2,61\%, dan responden yang menjawab sangat tidak setuju sebanyak 0,2\%. Dari keseluruhan jawaban responden, terdapat $48,8 \%$ karyawan menjawab kurang setuju dan terdapat $48,39 \%$ responden yang memilih jawaban sangat setuju dan setuju dimana persentase jawaban mereka tersebut berada di antara skor penilaian lebih kecil dari 50 dengan katergori sangat tidak baik. Sementara itu, terdapat 2,63\% responden menjawab tidak setuju dan sangat tidak setuju.

Responden yang menjawab sangat setuju adalah dengan rata-rata $18 \%$, responden yang menjawab setuju adalah rata-rata $44,79 \%$, responden yang menjawab kurang setuju adalah rata-rata 30,69\%, responden yang menjawab tidak setuju rata-rata sebanyak $5,46 \%$, dan responden yang menjawab sangat tidak setuju sebanyak 1,06\%. Dari keseluruhan jawaban responden, terdapat $30,69 \%$ karyawan menjawab kurang setuju dan terdapat $62,79 \%$ responden yang memilih jawaban sangat setuju dan setuju dimana persentase jawaban mereka tersebut berada di antara skor penilaian 60 sampai dengan 69 dengan katergori cukup baik. Sementara itu, terdapat $6,52 \%$ responden menjawab tidak setuju dan sangat tidak setuju.

\section{Uji Asumsi Klasik}

\section{Uji Multikolinearitas}

Hasil uji multikolinearitas diketahui bahwa nilai tolerance dari hasil uji multikolinearitas untuk variabelkualitassumberdayamanusia $\left(X_{1}\right)$ sebesar 0,360 , variabel komunikasi $\left(X_{2}\right)$ sebesar 0,347 dan variabel motivasikerja $\left(X_{3}\right)$ adalah 1,070 . Nilai VIF dari hasil uji multikolinearitas untuk variabel kualitas sumber daya manusia $\left(X_{1}\right)$ sebesar 2,776 , variabel komunikasi $\left(X_{2}\right)$ sebesar 2,882 dan variabel motivasi kerja $\left(X_{3}\right)$ sebesar 1,070 dimana nilai tolerance yang dihasilkan adalah $>0,10$ dan nilai VIF yang dihasilkan adalah $<10$, maka dapat disimpulkan bahwa tidak terjadi multikolinearitas atau tidak ditemukan adanya korelasi di antara variabel bebas yaitu kualitas sumber daya manusia, komunikasi, dan motivasi kerja dalam model regresi di dalam penelitian ini. 


\section{Uji Normalitas}

Hasil uji normalitas diketahui bahwa nilai $\mathrm{p}$ value Sig atau nilai signifikansi dari variabel kualitas sumber daya manusia adalah 0,200, variabel komunikasi adalah 0,200; dan nilai $\mathrm{p}$ value Sig atau nilai signifikansi dari variabel motivasi kerja adalah 0,063 ; dimana semua nilai $p$ value Sig atau nilai signifikansi yang dihasilkan adalah $>0,05$, maka dapat disimpulkan bahwa data yang diuji di dalam penelitian ini adalah berdistribusi normal.

\section{Analisis Regresi Linear Berganda}

Hasil analisis regresi linear berganda untuk pengaruh di antara variabel komunikasi, variabel komunikasi dan variabel motivasikerja terhadap variabel kinerja karyawan adalah sebagai berikut :

Tabel 3.Hasil Analisis Regresi Linear Berganda

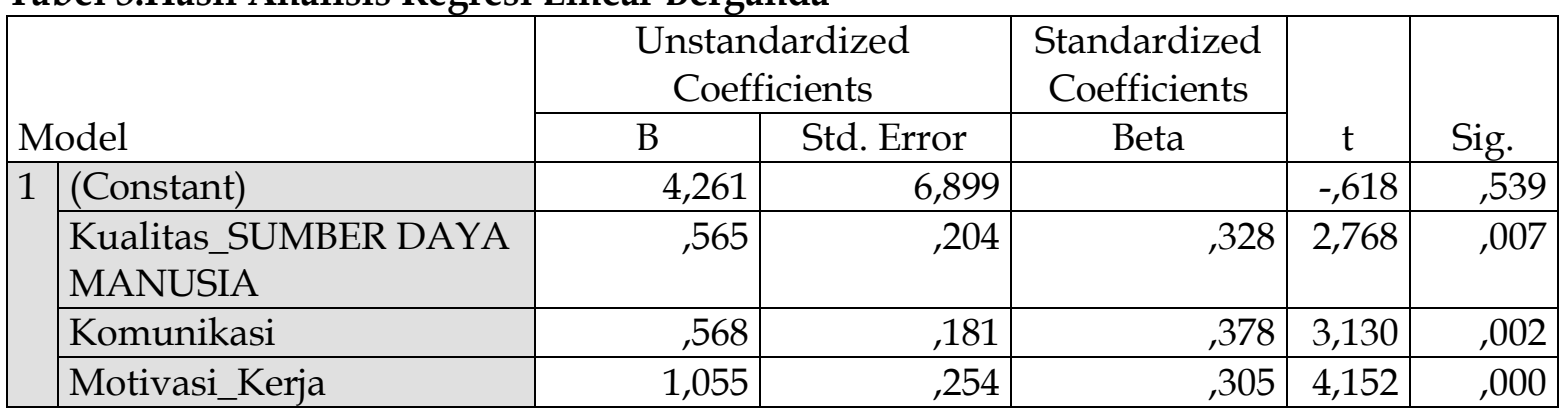

a. Dependent Variable: Kinerja Karyawan

Sumber : Data Diolah Dari Hasil Penelitian, 2019

Berdasarkan tabel 7 dapat diketahui bahwa koefisien a adalah 4,261; koefisien $b_{1}$ adalah 0,565 ; koefisien $b_{2}$ adalah 0,568 dan koefisien $b_{3}$ adalah 1,055 . Koefisien a merupakan

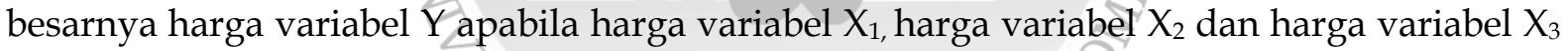
$=0$, sedangkan koefisien $\mathrm{b}$ adalah nilai koefisien regresi variabel $\mathrm{Y}$ atas variabel $\mathrm{X}_{1}, \mathrm{X}_{2}$ dan variabel $\mathrm{X}_{2}$.

Berdasarkan tabel 8 dapat diketahui bahwa nilai komponen a atau konstanta sebesar 4,261merupakan nilai $Y$ apabila nilai $X_{1} X_{2}$ dan nilai $X_{3}=0$; nilai komponen $b_{1}$ atau koefisien regresi untuk variabel kualitas sumber daya manusia sebesar 0,565menandakan bahwa variabel kualitas sumber daya manusia mempunyai hubungan yang searah dengan variabel kinerja karyawan yang artinya semakin baik kualitas sumber daya manusia yang diterapkan oleh pimpinan perusahaan terhadap bawahan, maka kinerja yang dihasilkan oleh karyawan akan semakin meningkat, sebaliknya semakin kurang baik kualitas sumber daya manusia yang diterapkan oleh pimpinan perusahaan, maka kinerja yang dihasilkan oleh karyawan akan semakin menurun.

Nilai komponen $b_{2}$ atau koefisien regresi untuk variabel komunikasisebesar 0,568menandakan bahwa variabel komunikasi mempunyai hubungan yang searah dengan variabel kinerja karyawan yang artinya semakin kuatkomunikasi yang diterapkan oleh pimpinan perusahaan, maka kinerja yang dihasilkan oleh karyawan akan semakin meningkat, sebaliknya semakin lemahkomunikasi yang diterapkan oleh pimpinan perusahaan, maka kinerja yang dihasilkan oleh karyawan akan semakin menurun. Nilai komponen $b_{3}$ atau koefisien regresi untuk variabel motivasi kerja sebesar 1,055 menandakan bahwa variabel motivasi kerja mempunyai hubungan yang searah dengan variabel kinerja karyawan yang artinya semakin tinggi motivasi kerja yang dirasakan oleh karyawan, maka karyawan akan menunjukkan kinerja semakin meningkat, sebaliknya semakin rendah motivasi kerja yang dirasakan oleh karyawan, maka kinerja karyawan semakin menurun. 
Berdasarkan hasil perhitungan uji signifikansi di dalam analisis regresi linear berganda diketahui bahwa nilai $\mathrm{p}$ value Sig atau nilai signifikansi dari pengaruh di antara variabel kualitas sumber daya manusia terhadap variabel kinerja karyawan adalah 0,007 dimana nilai $p$ value Sig atau nilai signifikansi yang dihasilkan adalah $<0,05$, maka dapat disimpulkan bahwa regresi pengaruh di antara variabel kualitas sumber daya manusiaterhadap variabel kinerja karyawan di dalam penelitian ini adalah signifikan. Nilai $p$ value sig atau nilai signifikansi dari pengaruh di antara variabel komunikasi terhadap variabel kinerja karyawan adalah 0,002 dimana nilai $p$ value sig atau nilai signifikansi yang dihasilkan adalah $<0,05$, maka dapat disimpulkan bahwa regresi pengaruh di antara variabel komunikasi terhadap variabel kinerja karyawan di dalam penelitian ini adalah signifikan. Nilai $\mathrm{p}$ value sig atau nilai signifikansi dari pengaruh di antara variabel motivasi kerja terhadap variabel kinerja karyawan adalah 0,000 dimana nilai $\mathrm{p}$ value sig atau nilai signifikansi yang dihasilkan adalah $<0,05$, maka dapat disimpulkan bahwa regresi pengaruh di antara variabel motivasi kerja terhadap variabel kinerja karyawan di dalam penelitian ini adalah signifikan.

\section{Uji Koefisien Korelasi Linear Berganda}

Hasil uji koefisien korelasi linear berganda untuk pengaruh di antara variabel kualitas sumber daya manusia, variabel komunikasi dan variabel motivasi kerja terhadap variabel kinerja karyawan adalah sebagai berikut :

Tabel 4.Hasil Uji Koefisien Korelasi Linear Berganda

\begin{tabular}{|l|l|r|r|r|}
\hline Model & \multicolumn{1}{|c|}{$\mathrm{R}$} & \multicolumn{1}{c|}{ R Square } & Adjusted R Square & Std. Error of the Estimate \\
\hline 1 &, $775^{\mathrm{a}}$ &, 601 &, 585 & 6,763 \\
\hline
\end{tabular}

Sumber : Data Diolah Dari Hasil Penelitian, 2019

Berdasarkan tabel 4 dapat diketahui bahwa hasil uji koefisien korelasi linear berganda untuk pengaruh antara variabelkualitas sumber daya manusia, variabel komunikasi dan variabel motivasi kerja terhadap variabel kinerja karyawan adalah 0,775 yang berada pada interval koefisien antara 0,600 - 0,799 dengan tingkat hubungan yang sangat kuat. Hal ini berarti kualitas sumberdayamanusia, komunikasi dan motivasi kerja mempunyai pengaruh yang kuat terhadap kinerja karyawan padaPT. Alexa Medika Medan.

\section{Uji Hipotesis Secara Parsial atau Uji T}

Hasil uji hipotesis parsial atau uji $t$ untuk pengaruh di antara variabel komunikasi, komunikasi dan motivasi kerja secara individual dalam menerangkan kinerja karyawan yang diuraikan tabel 3 di atas. Berdasarkan tabel 3 hasil uji hipotesis secara parsial atau uji tuntuk

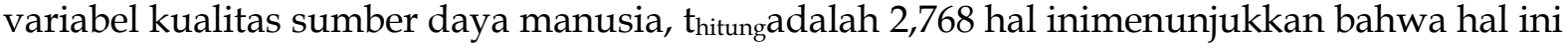
berarti $t_{\text {hitung }}>t_{\text {tabel }}(2,768>1,66)$ artinya kualitas sumber daya manusia mempunyai pengaruh yang positif dan signifikan terhadap kinerja karyawan pada PT. Alexa Medika Medan.Untuk variabel komunikasi, $t_{\text {hitung }}$ sebesar3,130, sedangkan $t_{\text {tabel }} 1,66$, hal ini berarti $t_{\text {hitung }}>t_{\text {tabel }}(3,130$ $>1,66$ ) artinya komunikasi mempunyai pengaruh yang positif dan signifikan terhadap kinerja karyawan padaPT. Alexa Medika Medan. Untuk variabel motivasi kerjat ${ }_{\text {hitung }}$ adalah 4,152, hal ini berarti $t_{\text {hitung }}>t_{\text {tabel }}(4,152>1,66)$ artinya motivasi kerjamempunyai pengaruh yang positif dan signifikan terhadap kinerja karyawan padaPT. AlexaMedika Medan.

\section{Uji Hipotesis Simultan atau Uji F}

Hasil uji hipotesis secara simultan atau uji $\mathrm{F}$ untuk pengaruh di antara variabel komunikasi, variabel komunikasidan variabel motivasi kerjasecara bersama-sama terhadap variabel kinerja karyawan adalah sebagai berikut : 
Volume 21 Nomor 1, Maret 2021

Tabel 5. Hasil Uji Hipotesis Simultan Atau Uji F

\begin{tabular}{|l|l|r|r|r|r|r|}
\hline \multicolumn{2}{|l|}{ Model } & Sum of Squares & df & Mean Square & F & \multicolumn{1}{c|}{ Sig. } \\
\hline \multirow{2}{*}{1} & Regression & 5434,950 & 3 & 1811,650 & 39,607 &, $000 \mathrm{~b}$ \\
\cline { 2 - 7 } & Residual & 3613,556 & 79 & 45,741 & & \\
\cline { 2 - 8 } & Total & 9048,506 & 82 & & & \\
\hline
\end{tabular}

a. Dependent Variable: Kinerja_Karyawan

b. Predictors: (Constant), Motivasi Kerja, Kualitas Sumber Daya Manusia, Komunikasi, Komunikasi

Sumber : Data Diolah Dari HasilPenelitian, 2019

Berdasarkan tabel 5 dapat diketahui bahwa $F_{\text {hitung }}$ yang dihasilkan dari uji hipotesis secara simultan atau uji $\mathrm{F}$ untuk pengaruh variabel kualitas sumber daya manusia, komunikasi dan motivasi kerja secara bersama-sama terhadap kinerja karyawan adalah

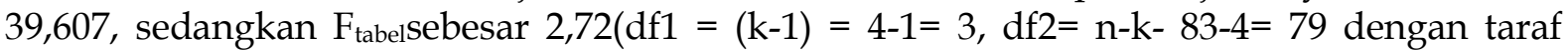
kesalahan $5 \%)$, hal ini berarti $F_{\text {hitung }}>F_{\text {tabel }}(39,607>2,72)$ yang artinya bahwa variabel kualitas sumber daya manusia, komunikasi dan motivasi kerja mempunyai pengaruh yang positif dan signifikan terhadap kinerja karyawan padaPT. Alexa Medika Medan.

\section{Perhitungan Koefisien Determinasi}

Hasil perhitungan koefisien determinasi untuk kontribusi di antara variabel komunikasi,komunikasi dan motivasi kerjaterhadap kinerja karyawan adalah sebagai berikut:

Tabel 6.Hasil Perhitungan Koefisien Determinasi

\begin{tabular}{|l|r|r|r|r|}
\hline Model & \multicolumn{1}{|c|}{$\mathrm{R}$} & \multicolumn{1}{c|}{ R Square } & Adjusted R Square & Std. Error of the Estimate \\
\hline 1 &, $775^{\mathrm{a}}$ &, 601 &, 585 & 6,763 \\
\hline
\end{tabular}

Sumber : Data Diolah DariHasilPenelitian, 2019

Berdasarkan tabel 6 dapat diketahui bahwa hasil perhitungan koefisien determinasi untuk kontribusi di antara variabel komunikasi,komunikasi dan motivasi kerja terhadap kinerja karyawan adalah 0,585 atau $58,5 \%$. Hal ini menunjukkan bahwa kontribusi dari variabel kualitas sumber daya manusia, komunikasidan motivasi kerja untuk meningkatkan variabel kinerja karyawan adalah sebesar 0,585 atau 58,5\%, sedangkan sisa 0,415 atau 41,5\% dipengaruhi oleh variabel lain yang tidak diteliti di dalam penelitian ini, seperti kepemimpinan, lingkungan kerja, kompetensi, komitmen kerja dan lain sebagainya.

\section{PEMBAHASAN}

Berdasarkan analisis deskriftif variabel kualitas sumber daya manusia, responden yang menjawab sangat setuju adalah dengan rata-rata $28,67 \%$, responden yang menjawab setuju adalah rata-rata $47,23 \%$, responden yang menjawab kurang setuju adalah rata-rata $18,31 \%$, responden yang menjawab tidak setuju rata-rata sebanyak 5,06\%, dan responden yang menjawab sangat tidak setuju rata-rata $0,72 \%$. Dari keseluruhan jawaban responden, terdapat $18,31 \%$ responden menjawab kurang setuju dan terdapat $75,9 \%$ responden yang memilih jawaban sangat setuju dan setuju dimana persentase jawaban mereka tersebut berada di antara skor penilaian 70 sampai dengan 79 dengan katergori baik.Prawirosentono (2017:67) menyatakan bahwa semakin tinggi kualitas sumber daya manusia yang dimiliki oleh karyawan dan sesuai dengan tuntutan pekerjaan maka kinerja karyawan juga akan semakin meningkat. Teori ini didukung dengan hasil analisis regresi linear berganda dengan persamaan $Y=4,261+0,565 X_{1}+0,568 X_{2}+1,055 X_{3}$. Nilai koefisien regresi kualitas sumber daya manusia sebesar 0,565 yang bernilai positif. Ini berarti jika kualitas sumber daya

Analisis Pengaruh Kualitas Sumber Daya Manusia, Komunikasi, dan Motivasi Kerja Terhadap 56

Kinerja Karyawan Pada PT. Alexa Medika Medan

Oleh : Sahat Simbolon 
manusia meningkat, maka kinerja karyawan juga akan meningkat. Teori ini juga didukung oleh hasil penelitian $t_{\text {hitung }}>t_{\text {tabel }}(2,768>1,66)$ yang artinya variabel kualitas sumber daya manusia berpengaruh positif dan signifikan terhadap kinerja karyawan PT Alexa Medika Medan.

Hasil analisis deskripsi dari penelitian variabel komunikasi terhadap kinerja karyawan PT Alexa Medika Medan adalah sebagai 77,47\%, skor penilaian 70 sampai dengan 79 termasuk dalam katergori baik. Sementara itu, masihada 8,08\% responden yang kurangsetuju, tidaksetujudansangattidaksetuju yang menunjukkan masih ada kelemahan dalam komunikasi di PT AlexaMedika Medan.Sunyoto (2017:82) yang menyatakan bahwa komunikasi organisasi yang baik dapat memicu kinerja menjadi semakin baik dan untuk mendapatkan hasilkerja yang optimal maka diperlukan komunikasi yang berkualitas dan mampu dipahami oleh pegawai. Ketika perusahaan itu berharap dapat bekerja dalam sebuah manajemen yang efisien, maka di dalamnya harus dilakukan langkah-langkah komunikasi secara terencana untuk meningkatkan kemajuan sebuah perusahaan. Teori ini didukung dengan hasil analisis regresi linear bergan dadenganpersamaan $Y=4,261+0,565 X_{1}+0,568$ $X_{2}+1,055 X_{3}$. Nilai koefisien regresi komunikasi sebesar 0,5658 yang bernilaipositif. Ini berarti jika komunikasi meningkat, maka kinerja karyawan juga akan meningkat. Komunikasi adalah bentuk interaksi manusia yang saling mempengaruhi satu sama lain, sengaja atau tidak, secara verbal maupunnon verbal (Wiryanto,2015). Pengaruh Komunikasi dalam kinerja karyawan dibuktikan dari hasil $t_{\text {hitung }}>t_{\text {tabel }}(3,13>1,668)$ yang artinya komunikasi berpengaruh positif dan signifikan terhadap kinerja karyawan.

Wahyono (2016:78) menyatakan bahwa motivasi adalah kesediaan mengeluarkan tingkat upaya yang tinggi untuk mencapai tujuan organisasi. Menurut teori Wahyono tersebut, maka dapat disimpulkan jika tanpa adanya motivasi kerja, maka tujuan organisasi tidak tercapai. Berdasarkan hasil deskripsi penelitian, diperoleh persentase sebesar $48,39 \%$, dimana persenta sejawaban mereka tersebut berada di antara skor penilaian lebih kecildari 50 dengan katergori sangat tidak baik. Terdapat 2,63\% karyawan menjawab tidak setuju dan sangat tidak. Hasil analisis regresi dengan persamaan $Y=4,261+0,565 X_{1}+0,568 X_{2}+1,055 X_{3}$. Nilai koefisien regresi motivasi kerja sebesar 1,055 yang bernilai positif. Ini berarti jika komunikasi meningkat, maka kinerja karyawan juga akan meningkat. Teori ini juga didukung oleh hasil uji $\mathrm{T}$ dengan hasilt $\mathrm{h}_{\text {itung }}>\mathrm{t}_{\text {tabel }}(4,152>1,668)$, artinya variabel motivasi kerja berpengaruh positif dan signifikan terhadap kinerja karyawan PT Alexa Medika Medan. Hasil penelitian tersebut sudah sesuai dengan teori Takacs (2018:1) yang menyebutkan bahwa motivasi kerja adalah kegiatan memfasilitasi karyawan dengan insentif untuk mendorong karyawan bekerja sesuai dengan cara yang diinginkan oleh organisasi. Jika motivasi meningkat, maka karyawan dapat bekerja sesuai keinginan organisasi yaitu pencapaian kinerja karyawan yang efektif dan efisien.

Kualitas sumber daya manusia, komunikasi dan motivasi kerja mempunyai peranan yang sangat penting dalam meningkatkan kinerja karyawan. Hal ini didukung keseluruhan jawaban responden untuk pernyataan dari variabel kinerja karyawan terdapat 62,79\% responden yang memilih jawaban sangat setuju dan setuju dimana persentase jawaban mereka tersebut berada di antara skor penilaian 60 sampai dengan 69 dengan katergori cukup baik. Sementara itu, terdapat $6,52 \%$ responden menjawab tidak setuju dan sangat tidak setuju. Berdasarkan hasil uji hipotesis simultan atau uji $\mathrm{F}$ di atas, maka dapat disimpulkan bahwa komunikasi, komunikasi dan motivasi kerja mempunyai pengaruh yang positif dan signifikan terhadap kinerja karyawan padaPT. Alexa Medika Medan.

Berdasarkan hasil perhitungan koefisien determinasi untuk kontribusi antara variabel Kualitas sumber daya manusia, komunikasi dan motivasi kerja terhadap variabel kinerja karyawan adalah 0,805 atau 80,5\%. Hal ini menunjukkan bahwa kontribusi dari variabel 
kepemimpinan visioner, komunikasi dan kompensasi untuk meningkatkan variabel kinerja karyawan adalah sebesar 0,585 atau 58,5\%, sedangkan sisa 0,415 atau 41,5\% dipengaruhi oleh variabel lain yaitu kepemimpinan, lingkungan kerja, komitmen kerja, dan lain-lain.

\section{Kesimpulan}

\section{KESIMPULAN DAN SARAN}

Berdasarkan hasil analisis deskriptif, variabel kualitas sumber daya manusia dan komunikasi termasuk dalam kategori baik, variabel kinerja karyawan termasuk dalam kategori cukup baik, variabel motivasi kerja termasuk dalam kategori sangat tidak baik dan kinerja berada pada kategori cukup baik. Berdasarkan hasil uji hipotesis secara parsial atau uji $\mathrm{T}$, variabel kualitas sumber daya manusia, komunikasi dan motivasi kerja dimana $t_{\text {hitung }}>$ $t_{\text {tabel }}$ yang artinya kualitas sumber daya manusia, komunikasi dan motivasi kerja secara parsial berpengaruh positif dan signifikan terhadap kinerja karyawan PT Alexa Medika Medan.

Berdasarkan hasil uji $\mathrm{F}$ ( $\left.\mathrm{F}_{\text {hitung }}>\mathrm{F}_{\text {tabel }}\right)$, maka variabel kualitas sumber daya mansuia, komunikasi, dan motivasi kerja secara simultan memiliki pengaruh positif dan signifikan terhadap kinerja karyawan PT Alexa Medika Medan.Hasil perhitungan koefisien determinasi menunjukkan bahwa 58,5\% kinerja karyawan dipegaruhi oleh kualitas sumber daya manusia, komunikasi, dan motivasi kerja. Sementara sisa $41,5 \%$ ditentukan oleh faktor-faktor lain seperti disiplin kerja, kepemimpinan, kompensasi, dan sebagainya.

\section{Saran}

Sebaiknya pimpinan dapat memberikan asuransi kesehatan kepada karyawan, memberikan kursus bahasa inggris kepada karyawan yang memerlukan pengetahuan bahasa asing di pekerjaan, pemberian perlindungan terhadap karyawan seperti pemerhatian hak-hak asasi karyawan dan pemberlakuan peraturan personalia yang sesuaidengan undang-undang perlindungan ketenagakerjaan, dan memberikan apresiasi kepada karyawan yang mencapai target. Pimpinan juga sebaiknya memberikan teguran dan sanksi kepada karyawan yang belum menunjukkan perbaikan-perbaikan kinerja, membatasi sarana dan fasilitas kepada karyawan secara wajar agar tidak terjadi pemborosan.

\section{DAFTAR PUSTAKA}

Danim, Sudarwan. 2015. Motivasi Kepemimpinan dan Efektivitas Koelompok. Jakarta: PT Rineka Cipta Utama

Handoko, Hani T. 2016. Manajemen Personalia dan Sumber Daya Manusia. Yogyakarta: Penerbit BPFE Yogyakarta

Lunenburg, Fred C. 2018. Motivating by Enriching Jobs. Huntsville: Keen Vision Publishing Mangkunegara, Anwar Prabu. 2017. Manajemen Sumber Daya Manusia Perusahaan. Bandung: Penerbit Rosda

Notoatmodjo, Soekidjo. 2017. Pengembangan Sumber Daya Manusia. Jakarta: Rineka Cipta

Ochola, George Uouma. 2018. Employee Motivation, An Organizational Performance Improvement Strategy. Nairobi: Moran (E.A.) Publishers Ltd.

Prawirosentono, Suyadi. 2017. Kebijakan Kinerja Karyawan. Yogyakarta: Penerbit BPFE Yogyakarta

Robbins, Stephen. 2015. Perilaku Organisasi. Jakarta: Penerbit Salemba Empat

Rahardjo, Dawam. 2015. Etika Ekonomi dan Manajemen. Yogyakarta: PT Tiara Wacana Yogya Sunyoto, Danang. 2017. Manajemen Sumber Daya Manusia. Jakarta: Caps Publishing Takacs, Ildiko. 2018. Phychology. Budapest: Typotex

Wahyono, Teguh. 2016. Manajemen Stratejik \& Analisis Kelayakan. Medan: Graha Ilmu 